Meta

Journal des traducteurs

Translators' Journal

\title{
Technological and Scientific Hebrew Terminology
}

\section{Ron Irmay}

Volume 43, numéro 1, mars 1998

La traduction et l'interprétation en Israël

Translation and Interpreting in Israel

URI : https://id.erudit.org/iderudit/003227ar

DOI : https://doi.org/10.7202/003227ar

Aller au sommaire du numéro

Éditeur(s)

Les Presses de l'Université de Montréal

ISSN

0026-0452 (imprimé)

1492-1421 (numérique)

Découvrir la revue

Citer cet article

Irmay, R. (1998). Technological and Scientific Hebrew Terminology. Meta, 43(1), 31-34. https://doi.org/10.7202/003227ar

\section{Résumé de l'article}

L'auteur décrit les procédures et mécanismes auxquels a recours en Israël la CCTT pour développer et mettre à jour une terminologie hébraïque normative en matière de science et de technologie. On évoque les processus lexicographiques et sociolinguistiques mis en œuvre pour former de nouveaux termes scientifiques en hébreu : synonymes, translittération, emprunt de termes internationaux, structures linguistiques, emplois vagues, poids du pays d'origine, etc. On décrit également les activités d'édition et d'informatisation de la CCTT au fil des ans. Afin de fournir au grand public un service terminologique régulièrement mis à jour, les bureaux de la CCTT mettent au point un dictionnaire sous forme de banque de données informatisée qui sera accessible également sur les réseaux locaux et internationaux. 


\title{
TECHNOLOGICAL AND SCIENTIFIC HEBREW TERMINOLOGY
}

RON IRMAY

Central Committee for Technological Terminology, Technion, Haifa, Israel

\begin{abstract}
Résumé
L'auteur décrit les procédures et mécanismes auxquels a recours en Israël la CCTT pour développer et mettre à jour une terminologie hébraïque normative en matière de science et de technologie.

On évoque les processus lexicographiques et sociolinguistiques mis en æuvre pour former de nouveaux termes scientifiques en hébreu: synonymes, translittération, emprunt de termes internationaux, structures linguistiques, emplois vagues, poids du pays d'origine, etc. On décrit également les activités d'édition et d'informatisation de la CCTT au fil des ans.

Afin de fournir au grand public un service terminologique régulièrement mis à jour, les bureaux de la CCTT mettent au point un dictionnaire sous forme de banque de données informatisée qui sera accessible également sur les réseaux locaux et internationaux.
\end{abstract}

\begin{abstract}
The author describes the procedures and mechanisms used by Israel's Central Committee for Technological Terminology (CCTT), a branch of the Academy of the Hebrew Language at Technion - Israel Institute of Technology, in the development and maintenance of standard Hebrew terminology in science and technology.

Lexicographic and sociolinguistic processes involved in the formation of new scientific terms in Hebrew, such as the effect of synonyms, transliteration, international terms and linguistic structure, fuzzy usage, pressure of countries of origin, etc., are referred to along with a broad survey of the Central Committee's printed and computerized output over the years.

In order to provide an updated terminological service that is easily accessible to the public, CCTT's Office at Technion is developing a computerized dictionary database for local and net-based multiuser environments.
\end{abstract}

Standard technological and scientific Hebrew terminology is created and revised by specialized professional committees consisting of faculty members of Technion (Israel Institute of Technology) and other universities in Israel, experts from industrial and engineering enterprises, and representatives of public authorities. Each committee includes members of the Academy of the Hebrew Language (AHL) as advisors on language matters.

Their sessions are coordinated by the Office of Technological Terminology (OTT) at Technion, Department of General Studies. OTT functions as the executive service of the Central Committee for Technological Terminology (CCTT) of the Academy and Technion, and cooperates with the Standards Institution of Israel (SII), which hosts common terminological subcommittees such as Automatic Data Processing (ADP), in translating terms in computers, quality assurance, standardization, etc.

OTT, in cooperation with other Technion faculties and laboratories, recruits students specializing in Information Systems at Technion's Faculties of Computer Science and Industrial Engineering together with advanced high school students participating in preacademic summer workshops (e.g. SCI-TECH international workshop organized by Tech- 
nion's Pre-Academic Studies Unit) for the computerization of its Dictionary knowledge base and for the development of its database infrastructure, in the framework of annual projects (R. Irmay 1995).

One of the main activities of CCTT is dictionary preparation, which includes the following stages (R. Irmay 1995):

- Collecting relevant professional dictionaries and glossaries, in Hebrew and foreign languages, efficiently covering the subject matter;

- Selecting an efficient subset of terms representing the subject domain (Ellis 1988);

- Translating terms from foreign language into Hebrew, using appropriate (Ornan 1994) transcription and transliteration rules where needed, borrowing existing terms from adjacent domains, whenever possible, and employing any other useful terminological tools or mechanisms (Nir 1993) that are acceptable in modern Hebrew (S. Irmay 1995);

- Preparing terms for the draft proposal, i.e. discussing them in professional subcommittees (e.g. Acoustics, Agricultural Machinery, Earth-moving Machinery, Machining Tools and Cutting, Production and Inventory Management);

- Submitting proposals for the Academy's approval via its Committee for Terminology and its Plenary Session (Irma \& Levy 1981);

- Preparing for printing: revising the proposal in view of the Academy's comments, introducing Hebrew pointing, and final editing of the bidirectional bilingual form;

- Publishing the final bilingual text of the dictionary in AHL / CCTT standard form.

\section{Terminological Activities in 1994-95}

OTT works in close cooperation with the Jerusalem staff of the Academy (AHL). In 1994-95 it updated and developed 11 dictionaries, including 10 at Technion in Haifa and one in cooperation with SII in Tel Aviv: Artificial Intelligence, Automatic Data Processing, Chemical Engineering and Thermodynamics, Cutting \& Grinding, Energy, Environmental Engineering, Machine Tools, Modern Physics, Organic Chemistry, Production and Inventory Management, and UNESCO thesaurus. Furthermore, Prof. S. Irmay, a member of the Academy and of CCTT and founder of OTT, reviewed dictionaries on Banking, Law, Microbiology, Plants and Sociology, prepared at AHL in Jerusalem.

In 1996, an important new subcommittee began to work on terms in Computers. Its scope complements (with partial overlap) that of SII's subcommittees on ADP.

\section{PUBLIC COOPERATION IN THE DEVELOPMENT AND USE OF TERMINOLOGY}

The following public bodies use CCTT terminology in close cooperation with OTT:

- Standards Institution of Israel (e.g. review by CCTT or OTT of special terms in the proposed standards, or cooperation in preparing SII's ADP dictionary).

- Israeli Government Institutions (e.g. Work Productivity Institute - Production and Inventory Management), Ministries (e.g. Energy, Hydrology, Transportation), and Services (e.g. Communications, or Israel Electric Corporation - Energy).

- The Office provides linguistic assistance (oral, facsimile or written) to Technion staff, institutions, public bodies, private companies, and the public at large. 


\section{DICTIONARIES IN PRINTED FORM}

CCTT dictionaries are developed and maintained in several media. They are stored in computerized databases and updated using the Internet, and are distributed to the general public as separate specialized printed dictionaries or via Internet as single terms in response to queries.

The dictionaries, without definitions, are distributed in book form by the Academy in Jerusalem and by the academic bookshop at Technion in Haifa (Michlol). Since 1995, AHL has undertaken to publish CCTT dictionaries, starting with Artificial Intelligence and Modern Physics. Some of the dictionaries are published by Israeli and International institutions, such as SII (separate chapters of the $A D P$ dictionary or bilingual index, also to be published in book form), Israel's Water Authority (Environmental Engineering), the World Energy Conference (Energy), etc. Prof. S. Irmay's Encyclopedic Dictionary of Technological and Scientific Terms (ca. 200,000 terms), with definitions of terms in Hebrew and English equivalents, provides a comprehensive computerized database for both CCTT's terms approved by AHL and yet unapproved terms used in practice.

The dictionary is being prepared for publication in 1996, in the form of a computerized electronic dictionary (on CD) and later in book form.

\section{COMPUTERIZATION OF THE TERMINOLOGICAL KNOWLEDGE BASE}

Computerized bilingual dictionaries, maintained in a central database at OTT, serve as references for terminological activities in professional subcommittees, and for the generation and updating of further specialized scientific and technological dictionaries. In order to enhance the CCTT database, OTT is developing an advanced computer-integrated bilingual environment for the integration of individual dictionaries into a multiuser dictionary database, allowing for easy terminological cross-referencing between draft-proposals and final dictionaries (R. Irmay 1995).

\section{DEVELOPMENT OF HEBREW TERMINOLOGY VIA LAN AND INTERNET}

The dictionary database was initially developed in a local multiuser environment using MAGIC application development system, to serve OTT staff and colaborators. It was further developed into a more general multiuser environment, for its future integration within various LANs and Internet, and with remote dictionary databases (R. Irmay 1995). In order to provide an updated continuous terminological service, OTT is developing a WorldWide Web-based user interface between Web-users on the Internet and its dictionary database. This $\boldsymbol{W} \boldsymbol{W} \boldsymbol{W}$ environment, endowed with appropriate Hebrew fonts (developed for Internet at the Hebrew University of Jerusalem as a tool for remote instructionware), provides the graphical capabilities required for the remote display of pointed Hebrew text on the net. Netscape web browser's hyperlink mechanism allows remote automatic downloading of essential Hebrew-oriented environment elements.

In the first place, this interface will enable Web users to retrieve single terms or translations thereof by simple term-queries activated by a "term search" button in Technion's WWW HomePage (one of various search buttons provided by the WWW environment).

Once this quasi unilateral service works well and becomes common practice, it will be expanded into a bilateral interactive mechanism that will support a novel form of distributed terminological committee sessions. Such a committee will no longer be as restricted in place and time as today's committees are, which hinders their ability to cope 
with the hordes of technological terms that are pressing hard against our walls, requiring translation or at least transliteration.

These developments will gradually allow future distribution of CCTT standard terminology within Technion LANs and Internet, and will also enable the efficient integration of CCTT's expanding terminological knowledge base with the Academy's remote dictionary database in Jerusalem, and enhance efficient interaction with SII and other Hebrew-oriented textual databases.

One may also envisage a similar evolutionary interaction \& integration process generating a living multilingual knowledge base (Eco 1994).

\section{REFERENCES}

ECO, Umberto (1994) : La recherche de la langue parfaite, Paris, Seuil.

ELLIS, W. P. (1988) : "Management of Terminology in Standards Organizations", Standardization of Technical Terminology: Principles \& Practices (second volume).

STREHLOW, R. A. (Ed.) (1988) : STP 991, American Society for Testing \& Materials, Philadelphia, pp. 62-70.

IRMAY, Ron (1984) : "English-Hebrew Dictionary of Terms in Artificial Intelligence, Multiobjective Choice \& Decisionmaking, Dynamic Programming, Expert Systems and Stereophonic Systems", Appendix to: Applications of Dynamic Programming to Multiobjective Decisionmaking, Msc. thesis, Technion, Haifa, Israel.

IRMAY, Ron (1995) : "Computerized Hebrew at Technion", Proceedings International Conference on Future and Communication, Technion, Department of General Studies, Haifa, Israel, May 1995.

IRMAY, S. (1995) : "Interaction between Technology and the Hebrew Language", Proceedings International Conference on Future and Communication, Technion, Department of General Studies, Technion, Haifa, Israel.

IRMAY, Shragga \& Yaakov LEVY (1981): Internal Standards Proposed to the Academy of the Hebrew Language, CCTT, June 1981.

NIR, Rafael (1993) : Word Formation in Modern Hebrew, Open University of Israel, Tel-Aviv.

ORNAN, Uzi (1994) : Basic Concepts in "Romanization" of Scripts, TR\#LCL94-5, Laboratory for Computational Linguistics, Computer Science, Technion, March 1994. 